\title{
アカモクの成長と生育環境に関する数学モデル*
}

$$
\begin{array}{r}
\text { 三宮信夫 }{ }^{* *} \text { ・鮑 } \\
\text { 坂 本 }
\end{array}
$$

\section{A Mathematical Model for Growth of Sargassum Horneri and Its Environment*}

\author{
Nobuo SAnNomiYa ${ }^{* *}$, Ermin Bao**, Hiroshi NAKAmine**, \\ Wataru SAKAMOTO ${ }^{* * *}$ and Kotaro OGINo ${ }^{* * * *}$
}

\begin{abstract}
Seaweed plays an important role in aquatic ecosystem. It supplies nutrient and provides the place of life for many kinds of living organism in the sea. In order to control the marine resources reasonably, a study on the growth dynamics of seaweed is necessary.

First, effects of solar radiation and water temperature on photosynthetic activity are considered. Secondly, a seasonal effect is introduced as a physiological phenomenon. Finally, a mathematical model of growth dynamics of Sargassum horneri is constructed from the idea of operating these effects multiplicatively. The model parameters are determined on the basis of the observation data which were measured for Sargassum horneri at Notojima Aquarium, Ishikawa Prefecture. By a computer simulation, the weight of Sargassum horneri is estimated for any change of the environmental conditions.
\end{abstract}

\section{1. 緒 言}

200 海里体制のもとでわが国の沿岸漁業を発展させる 一つのアプローチとして, 栽培漁業が産学官協同研究の あとで各地で試みられている. 人間と水産資源のかかわ りあいは，乙れまで最大の収穫を得るためにいかに効率 的に漁獲を行うべきかという立場から，将来にわたって この資源を安定に利用するために適正な捕獲量をいかに 定めるべきかという課題を経て, さらに水産資源をつく り育てるにはどうすればよいかという問題に発展してき $た^{1), 2)}$.

しかしての問題は, 生育環境す成長の状況む観測でき, かつ人間によって操作（制御）可能な農業の場合とは異 なり, 水産業では観測が困難な広大な海洋の中で, 生物

\footnotetext{
* 原稿受付 1992. 3. 27

** 京都工芸繊維大学 工芸学部 Department of Electronics and Information Science, Kyoto Institute of Technology; Matsugasaki, Sakyo-ku. Kyoto 606, JAPAN

*** Faculty of Agriculture, Kyoto University ; Kitashirakawa, Sakyo-ku, Kyoto 606, JAPAN

**** Notojima Aquarium ; Notojima-machi, Ishikawa 92602, JAPAN

Key Words : modeling, ecological system, growth dynamics, seaweed, aquarium.
}

間で繰り広げられる生存競争を海洋生態系として取り扱 わなければならない点で, 極めて難解である. システム 工学は本来そのような問題に挑戦すべきであるが, 工学 システムのようにデータが容易に得られないととが障害 となって, 乙の問題を扱うのは容易でなかった.

水産資源としてはまず魚貝類を想起するが，海中にお ける植物む海洋生態系では最す低次のレベルで生産者と して重要な位置を占めている．植物に関してはてれまで、 植物プランクトンに関する研究 ${ }^{33) 4)}$ がなされているが, 海藻をシステム工学の対象とする研究は皆無である. 植 物プランクトンの現存量の変動を表わすモデルは, 成長 のみならず動物による摂食や乱流による拡散が主要な要 因となる，乙れに対して，海藻は移動がなく，生育環境， 成長状況之も比較的観測が容易である. また, 海藻の成 長に及ぼす環境の影響は, 植物プランクトンの場合と異 なっている.

本研究では, 上に述べた点に着目してシステム工学の 手法を用いて, 沿岸岩礁域で藻場を形成するアカモク （褐藻類ヒバマタ目ホンダワラ科）の成長の動態モデル を作成する. すなわち，まずアカモクの成長に関する主 要な環境要因である水温抢よび光強度に関して, 実測デ 一夕に基づいてその年変化をモデル化する．つぎに，乙 
れらの環境要因による光合成への影響を調べて，それぞ れの関係をモデル化する. さらに, 海藻自身の内的要因 である季節効果を導入し，てれらの要因を総合的に考え てアカモク単体の成長動態モデルを構築する.

実測データとしては, 石川県のとじま臨海公園水族館 の水槽内で育成されているアカモクのデータ)をむとに, モデルに含まれるパラメータをシミュレーションによっ て決定する. また, アカモクの成長が環境条件によって どのように変化するかをシミュレーションによって考察 する.

\section{2. 海洋生態系における海藻の位置付け}

海洋生態系は，物質の循環やエネルギーの流れを考え ると, 生産者, 消費者, 分解者亡無機環境の四つの部分 に分けることができる ${ }^{6)}$. 生産者としては植物プランク トンおよび海藻，消費者としては主として魚貝類がある. 分解者（菌類）は生物体を分解して, 生態系に栄養塩を 供給する. 無機環境としては, 媒質（水, 空気など）お よび基層（岩石, 砂, 土, 泥）がある. さらに, 物質代 謝に関与するエネルギーとして, 光があり, 必要な物質 として二酸化炭素, 水, 酸素, 栄養塩抢よび有機物を考 える.

光合成を営む海藻は太陽の光エネルギーを化学エネル ギーに変換し, 無機物から有機物を合成しているので, 生態系の中で生産者としての地位を占めている. 生態系 に扔ける消費者である魚貝類は, 直接または間接に生産 者に依存して生活している，すなわち，海藻は消費者の 餌となることによって栄養を供給しているだけでなく, 海洋の沿岸部では大形の海藻が海中林と呼ばれる密生し た群落を形成することにより, 魚類の産卵や稚魚の生育, および成魚の生活場所を提供する. てのような理由で海 藻はバランスのとれた水界生態系の維持に重要な役割を 果たしているといえる.

\section{3. 生育環境のモデリング}

\section{1 考慮すべき環境要因}

海藻の成長は太陽エネルギーを利用するので, 光の強 度が物理的な環境条件の中で最あ重要である. 次に考慮 すべき環境条件として水温が挙げられる. 温度は生体反 応の進行に関係する要因であり, 海藻細胞の増殖は細胞 の中の生体反応の総合的な結果であるから，乙の反応の 持つ温度特性を反映した温度依存性を示すことになる。 海岸の科学的な水質環境については, 様々な化学物質が 溶存し, あるものは海藻の栄養として利用され, 他のも のは逆に阻害的に㗢く.

本研究では，石川県鹿島郡にあるのとじま臨海公園水
族館に执いて測定されたアカモクの生育デー夕をあとに, その成長モデルを構築する. アカモクは, 本州全沿岸に 扔いて外海あるいは内湾の 1 10 $\mathrm{m}$ の深さのと乙ろに生 育している海藻で, 主枝長（または藻体長）が $5 \sim 10 \mathrm{~m}$ に達する。

のとじま臨海公園水族館では, 直径 $20 \mathrm{~m}$ の 8 角形ド 一ナツ型屋外水槽に, 海藻の展示と飼育魚類の好適な生 棲場の確保を目的としてアカモクを移植し，1986 年よ りその成長を観察し続けてきた5). 環境要因の測定も, 水温は 1987 年より, また光強度は 1989 年より開始され た. な拉, 乙の水槽内では栄養塩濃度がほとんど飽和の 状態になっていると思われるので, 環境要因としては, 光強度と水温のみを考える.

アカモクは 1 年生の海藻である. 年間の成長過程は, 9 月上旬に新植物体が散見され，11月以降に水温が低 下するにつれて成長は促進し，1月２月にかけて成長 速度が最大になる，4〜 月には成長量が最大に達し， 5 月下旬には徐々に葉体の先端より枯死流出してその生活 史を完了する. 同時に, 次の世代へ向けて幼胚がまかれ, 生命が継承される. てのような成長過程をモデル化する ために, 時間 $t$ (day) の原点を 9 月 30 日にとり, それ 以後約 8 か月の期間 $(1 \leq t \leq 250$, すなわち 10 月 1 日よ り翌年 6 月 7 日まで), つまり藻体を肉眼で目視観察で きる頃から成長量が最大に達する頃までの期間を考察の 対象とする.

\section{2 光強度の年変化}

光強度のデー夕は, 屋外水槽の水深 $4 \mathrm{~m}$ のと乙ろで 測定された. デー夕数は, 1989 年 2 月から 1990 年 1 月 までの 1 年間のうち 26 日分である. その值は 1 時間で とに測定された 1 日あたり 13 個の測定值を基にして 1 日の日射量 $\left(\mathrm{E} / \mathrm{m}^{2} \cdot \mathrm{day}\right)$ として算出された. Fig. 1 に そのグラフを示す.

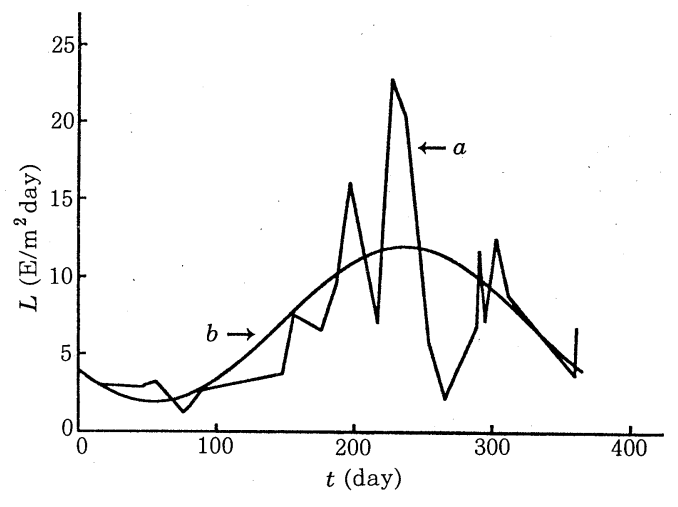

a : Observation value

b : Value obtained by equation (1)

Fig. 1 Seasonal variation of solar radiation 
データを分析して光強度の周期性を考慮すると, 第 $t$ 日における光強度 $L(t)$ は次のように与えられる.

$$
L(t)=A_{1}+A_{2} \cos \frac{2 \pi\left(t-t_{L}\right)}{365}
$$

ここに, パラメータ $A_{1}$ は一年の平均日射量を表わし， $A_{2}$ は年間日射量の変化幅で, $t_{L}$ は日射量が最太になる 日である。

測定值から最小二乗法を用いてパラメー夕 $A_{1}, A_{2}$ お よび $t_{L}$ を求めると, 次のような值が得られた.

$$
\begin{aligned}
A_{1} & =6.90 \mathrm{E} / \mathrm{m}^{2} \cdot \text { day } \\
A_{2} & =5.01 \mathrm{E} / \mathrm{m}^{2} \cdot \text { day } \\
t_{L} & =237 \mathrm{day}(5 \text { 月 } 25 \text { 日に相当) }
\end{aligned}
$$

Fig. 1 には, 光強度のモデル（1）のグラフも示してい る. 以後の議論にため光強度の值を瞬時値に換算すると, 次のようになる.

$$
L(t)=147.4+106.9 \cos \frac{2 \pi(t-237)}{365}\left(\mu \mathrm{E} / \mathrm{m}^{2} \mathrm{~s}\right)
$$

\section{3 水温の年変化}

のとじま臨海公園水族館では毎日午前 9 時に水温を測 定しており，1987 年 1 月から 3 年間分のデータが得られ ている. ここでは，乙のデータを平均し，さらに各月の 上旬, 中旬, 下旬で平均したものを用いる. 温度年変化 の周期性を考慮して，第 $t$ 日に打ける温度を $\theta(t)\left({ }^{\circ} \mathrm{C}\right)$ としてモデル化すると, 光強度の年変化と同様に三角関 数で近似することができ，次式を得る.

$$
\theta(t)=B_{1}+B_{2} \cos \frac{2 \pi\left(t-t_{\theta}\right)}{365}
$$

ここに, $B_{1}$ は一年の平均水温, $B_{2}$ は年間水温変化幅で, $t_{\theta}$ は水温が最大になる日である.

水温デー夕から最小二乗法によりパラメータを求める

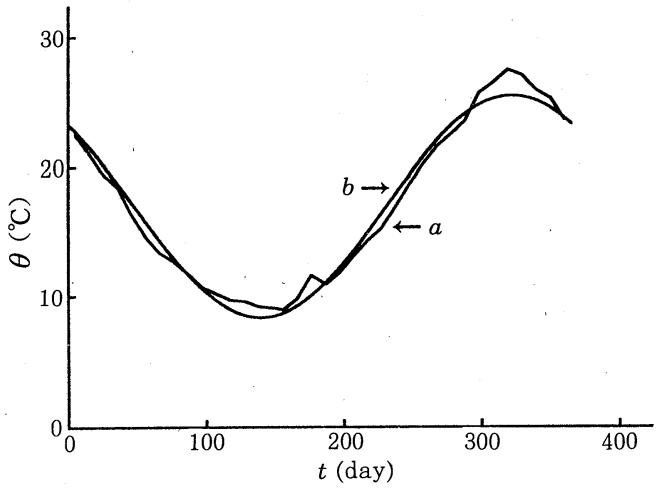

a : Observation value

b : Value obtained by equation (4)

Fig. 2 Seasonal variation of water temperature
と，のとじま臨海公園水族館の水温の年変化のモデルは 次式のようになる.

$$
\theta(t)=16.9+8.5 \cos \frac{2 \pi(t-322)}{365}
$$

ここに, $t_{\theta}=322$ は 8 月 18 日に対応する. Fig. 2 は, 水温の測定值およびモデル (4) 式のグラフを示す.

\section{4. 光合成速度に影響を与える要因のモデリ ング}

光合成速度は，光合成による二酸化炭素の固定および 酸素の発生という化学反応の速度である ${ }^{7)}$. 海藻は, 呼 吸もしている．乙の呼吸は，光合成之ほぼ逆の反応（す なわち，負の光合成速度）である. しかし，乙の呼吸に 対する光合成速度の值は小さいので，無視する.

本章では，光合成速度に影響を与える外的な環境条件 の効果として, 光強度効果执よび温度効果を取り上げる. また，海藻に固有な性質に基づく内的な効果として季節 効果を考慮して，それぞれのモデルを構築する.

\section{1 光強度効果}

光合成速度は弱光域に执いては光強度に比例し，それ よりも光強度が増加するにつれて, 光合成速度の増加率 は低下し，ついには光飽和点に達する. 植物プランクト ンの場合には，強光域において光合成速度が低下する強 光阻害という現象がみられるが3), 海藻の場合には通常 そのような現象は生じない。

光強度効果 $P_{L}$ は, 光合成速度と光強度 $L$ の関係を 示すものである. 便宜上, $P_{L}$ は 0 と 1 の間の值をとる ように正規化する. この $P_{L}$ のモデルは，その飽和特性 を考慮すると次のような指数関数で近似するてとができ る.

$$
P_{L}=1-\exp \left(-\frac{L}{L_{0}}\right)
$$

ここに，光強度 $L$ は瞬時值 $\left(\mu \mathrm{E} / \mathrm{m}^{2} \mathrm{~s}\right)$ とする.

パラメータ $L_{0}$ の值を決定するために，アカモクの光 合成に対する光強度の影響を調べた高の実験データ 用いる. 乙の実験は，1986 年 8 月に表面水温 $27 \sim 29{ }^{\circ} \mathrm{C}$ の舞鶴湾でアカモク幼体の光合成を測定したあのである. 光強度は日射強度なので, 水深 $4 \mathrm{~m}$ に打ける光強度值に 換算して用いた．乙のデータをあとにパラメータ $L_{0}$ を 求めると, 次の值を得た.

$$
L_{0}=55\left(\mu \mathrm{E} / \mathrm{m}^{2} \mathrm{~s}\right)
$$

Fig. 3 は, 高による測定值 (○印) と（5) 式のモデル (実線) の関係を示す.

\section{2 温度効果}

温度は，主として $\mathrm{CO}_{2}$ 固定過程に大きな影響を与え 


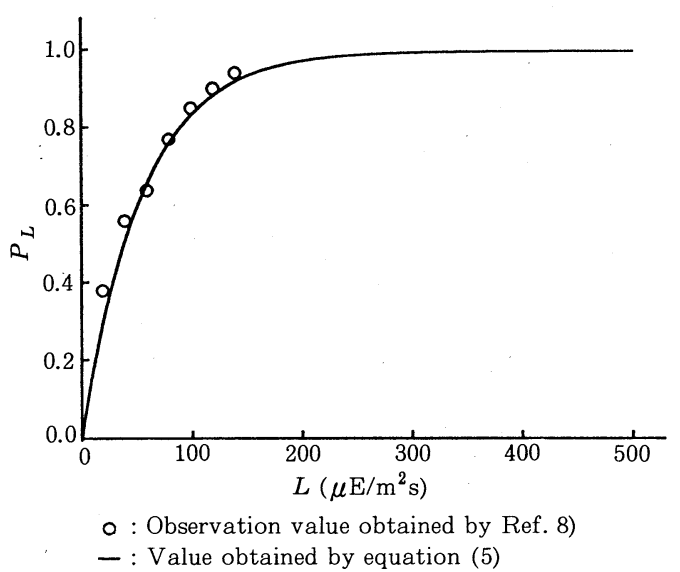

Fig. 3 Graph of solar radiation effect

る6). すなわち, 温度の上昇に伴って, 酸素の活性が高 まるのに対応して $\mathrm{CO}_{2}$ 固定速度が高まる. しかし, あ る温度を越えると, $\mathrm{CO}_{2}$ 固定系の酸素の活性がさらに 高まることが可能な温度にも関わらず，呼吸による $\mathrm{CO}_{2}$ 放出速度がより促進されるために, 光合成速度は低下す る. 光合成速度の低下の他の理由としては, 高温におけ る光化学反応の不活性化任基づく炭素固定速度の低下に あると考えられる. したがって, 光合成速度を最大にす る温度が存在することになる。

温度効果 $P_{\theta}$ は, 水温 $\theta$ と光合成速度の関係を表わす あのである。これに対する実験データとして, Gaoに よる舞鶴湾で測定されたアカモクの光合成速度の温度依 存性に関するデータ9) がある. このデー夕は 12 月に水 面の日射強度 $600 \mu \mathrm{E} / \mathrm{m}^{2} \mathrm{~s}$ の条件下で測定されたもの である.

本論文では，温度効果を次のようにモデル化する.

$$
P_{\theta}= \begin{cases}1-C_{0}\left(\theta-\theta_{0}\right)^{2} & \theta \geq \theta_{0} \text { のとき } \\ 1-C_{1}\left(\theta-\theta_{0}\right)^{2} & \theta \leq \theta_{0} \text { のとき }\end{cases}
$$

アカモクの光合成速度に対する最適な温度 $\theta_{0}$ は $25^{\circ} \mathrm{C}$ である ${ }^{9)}$. この実験のデータが 0 と 1 の間の值（相対値） を取るように規格化してから，参考文献 9）のデータに 基づいて最小二乗法によってパラメータ $C_{0}$ および $C_{1}$ を求めると, 次のようになる.

$$
C_{0}=0.005{ }^{\circ} \mathrm{C}^{-2}, C_{1}=0.002{ }^{\circ} \mathrm{C}^{-2}
$$

Fig. 4 は, Gaokよる測定值 (○印) と（6) 式のモデ ル（実線）の関係を示す.なお，植物プランクトンの場 合には, 至適温度域が高いので, $P_{\theta}$ は $\theta$ の単調増加関 数として表わされている3).

\section{3 季節効果}

光強度，温度などの外的な条件を一定にしておいても， 海藻は各成長段階で生理機能が大きく変化する ${ }^{9}$. 幼期

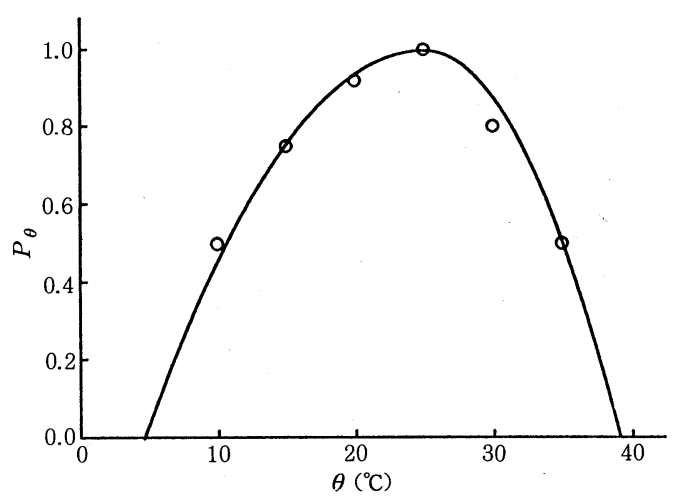

○: Observation value obtained by Ref. 9) - : Value obtained by equation (6)

Fig. 4 Graph of water temperature effect

には, 光合成を行うために重要な光合成色素（クロロフィ ルなど）の含有量む少ない，しかし，成長するにしたがっ て, 新しい細胞が増殖し, 原光合成色素体も分裂して新 しい光合成色素が生まれる. 乙れに伴って, 葉緑体が発 達して, 光合成速度は上がる. 成熟期になったときには, 葉緑体の大きさはもはや変化しないので, 光合成の速度 は一定になる. その後, 老化に伴って光合成色素が消失 するので, 光合成速度あ下がり, 最終的には 0 亿なって 枯死する. 一年生海藻のてのような成長時期による光合 成速度の変化を, 光合成の季節変化と呼ぶてとにする.

季節効果は, 光強度抢よび水温を一定の条件没設定し たとしても, 上に述べた植物固有の性質から光合成速度 が時間的に変動する現象を表わすすのである. 季節効果 のモデルは, てのような海藻の成長過程をあとに, 次の ように与える.

$$
P_{S}(t)=1-d\left(t-t_{0}\right)^{2}
$$

パラメータ $d$ 抢よび $t_{0}$ を定めるための実験デー夕は, Gaoによって発表されている ${ }^{9}$. 乙の実験は, 1987 年 10 月から 1988 年 6 月にかけて水温 $20^{\circ} \mathrm{C}$, 水面の日射強度 $600 \mu \mathrm{E} / \mathrm{m}^{2} \mathrm{~s}$ を一定にした条件下で行われた. この結 果を光合成速度の最大值が 1 となるように相対值に換算 したデータを用いてパラメータを求めると, 次の值が得 られた。

$$
d=0.00003 \mathrm{day}^{-2}, t_{0}=50 \mathrm{day}
$$

Fig. 5 は, Gao による測定值 (○印) と (7) 式のモデ ル (実線) の関係を示す. 同図をみると, 1 月および 2 月の測定点は小さい值となり，（7）式のグラフから離 れていることがわかる. 測定值をグラフ上にのせるため には，(7) 式の関数形をより複雑な形にしなければなら ない. 同図の○印は, 参考文献 9）に上れば, アカモク の上葉の測定データであり, 下葉の 2 月の測定值は相対 


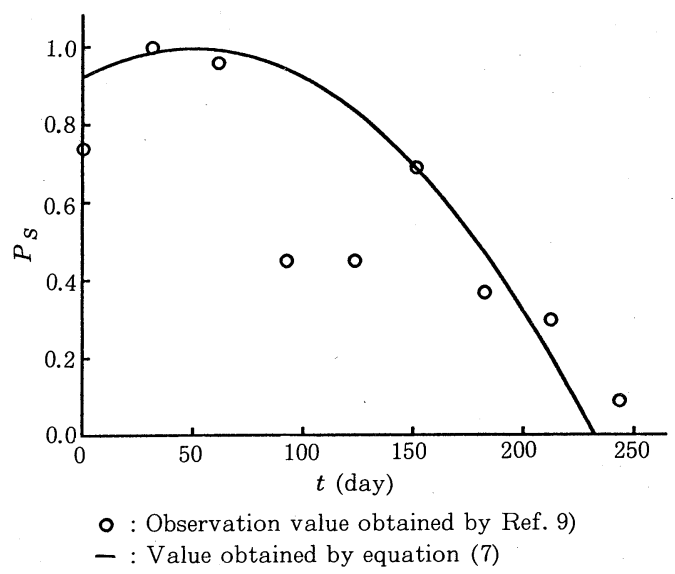

Fig. 5 Graph of season effect

的に大きい值が得られている，また，葉緑体の成長量む 1 月打よび 2 月は高いてとが示されている. 乙れらのデ 一夕を検討した結果，(7) 式の形は妥当であると考えて 曲線あてはめを行った。

\section{4 光合成速度モデル}

上に述べたように，光合成には複数の要因が作用して いる，その場合，ある要因があるレベルに固定されるな らば, ほかの要因がいくら最適なレベルに達していても, 光合成速度の最大值は固定された要因によって決まるあ る一定の値を超えるてとはできないと考えられる．乙て ではての考え方に基づいて，上に述べた環境要因および 季節要因は, 光合成速度に対して相乗的に作用すると仮 定して，次のモデルを考える.

$$
P(t)=P_{L}(t) \times P_{\theta}(t) \times P_{S}(t)
$$

ここに，(8) 式に抢ける $P_{L}(t)$ 打よび $P_{\theta}(t)$ は，それぞ れ (2) 式打よび (4) 式を光強度効果 (5) 式打よび温度効 果 (6) 式に代入して得られたあのである.

\section{5. アカモクの成長に関する動態モデル}

9 月 30 日を始点として第 $t$ 日目に扔けるアカモク単体 の重量を $N(t)(\mathrm{g})$ とする. また, 初期值として 10 月 1 日に打劧カモクの重量 $N(1)$ を与える. 第 $t$ 日目か ら第 $t+\Delta t$ 日目への重量の変化量を $\Delta N(t)$ とすると, アカモクの重量に対する動態モデルは次のような差分方 程式で表わされる.

$$
\begin{aligned}
N(t+\Delta t) & =N(t)+\Delta N(t) \\
& =N(t)+\left[\alpha P(t) N(t)-\beta N^{2}(t)\right] \Delta t
\end{aligned}
$$

とくに，1日でとの重量の変化を調べることができるよ うに，離散的な時間単位を $\Delta t=1$ とすると，

$$
N(t+1)=N(t)+\alpha P(t) N(t)-\beta N^{2}(t)
$$

(10) 式に扔いて, $P(t) N(t)$ の項は, 光合成によるア カモクの重量の増加分を表わすむのである. 乙の項に付 加されたパラメータ $\alpha$ はその影響を示す係数である. 一方，(10）式に抢いて $\beta N^{2}(t)$ の項は, $t$ ととあに $N(t)$ が無限大に増加するてとを抑制するすので，現実には過 密に生育するてとによる成長量の減少効果を表わしてい る. パラメータ $\beta$ はその係数である.

具体的に, 成長量の減少効果として次のようなととが 考えられる. すなわち, アカモク単体は同一環境条件下 で生活しているといっても, その上葉と下葉の受ける光 エネルギーは異なっている. 下葉の光合成速度は, 上葉 の面積が大きくなることに伴って，低下する．てのよう な原因で, 光合成速度 $P(t)$ は，主として上葉に対する あのである. 下葉の光合成速度の減少効果は, 上葉の面 積に比例するとみなして，アカモク単体に対しては，そ の速度が $\alpha P(t)$ より $\beta N(t)$ だけ低くなると考えられ る.乙のような減少効果を考えると，(10) 式に示され るように, $\beta N^{2}$ の項を導入する必要がある.

パラメー夕 $\alpha$ 抢よび $\beta$ の值を直接決定する実験デー 夕は存在しないので，ててではシミュレーションによっ て定めるととにする.

シミュレーションは，次のようにして行う．すなわち， (8) 式を (10) 式に代入すると $N(t)$ に関する離散時間シ ステムが得られる. これを計算するには，初期値 $N(1)$ およびパラメータ $\alpha, \beta$ を定めなければならない，乙て

\begin{tabular}{|c|c|c|}
\hline Observation data & Length & Weight \\
\hline February $16(t=139)$ & $380 \mathrm{~cm}$ & $72 \mathrm{~g}$ \\
\hline March $16(t=167)$ & $510 \mathrm{~cm}$ & $255 \mathrm{~g}$ \\
\hline April $\quad 20(t=202)$ & $540 \mathrm{~cm}$ & $450 \mathrm{~g}$ \\
\hline
\end{tabular}
では, 乙れらの量を仮定して $N(t)$ の值を求め, その値 ができるだけ実測データに一致するようにする.

Table 1 Observation value of Sargassum horneri's weight

のとじま臨海公園水族館で測定されたアカモク単体の 重さのデータは, Table 1 のように三日分の值が与えら れている5). よって, てのデータを用いて, $N(t)$ 亿関す るシミュレーションを行った，その結果，次の值が得ら れた.

$$
\begin{aligned}
& \alpha=0.126 \quad \mathrm{~g} / \mathrm{g} \cdot \text { day } \\
& \beta=0.000042 \mathrm{~g} / \mathrm{g}^{2} \cdot \text { day } \\
& N(1)=0.05 \mathrm{~g}
\end{aligned}
$$

Fig. 6 は, シミュレーションの結果得られたアカモク の成長曲線を示す。ただし, 図中の○印は重量の測定値 である. ての曲線は 10 月から翌年 5 月までの成長期に 抢けるアカモクの重量の動態を再現していると考えられ 


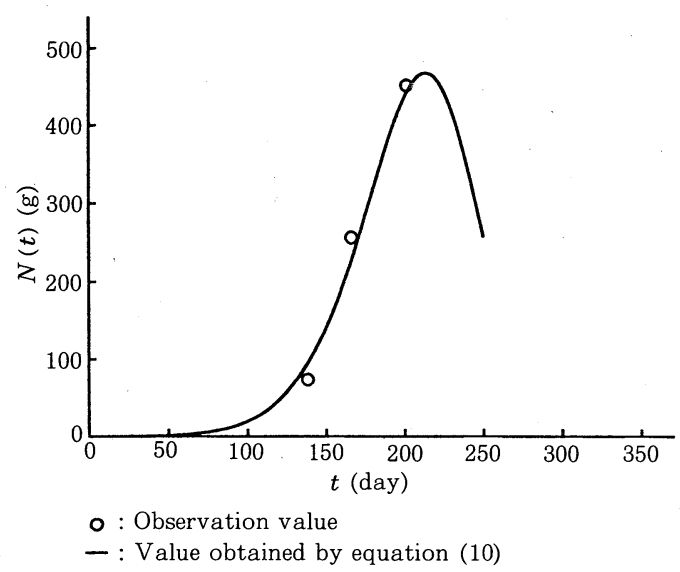

Fig. 6 Simulation result of seasonal variation of Sargassum horneri's weight

る. 成長曲線によると, 2 月中旬（ 2 月 10 日は $t=133$ に相当する）から 4 月にかけてアカモクの重量が著しく 增加する. 4 月下旬 ( 4 月 20 日は $t=202$ に相当する) から，その増加速度が減り，5月 1 日 $(t=213)$ で重量 は最大になる．その最大重量は $467 \mathrm{~g}$ である.

\section{6. 環境条件の变化が重量に及ぼす影響}

アカモク重量の動態モデル（10）式を用いる一つの目 的として，環境条件が変化するてとによりアカモクの成 長量がどのように増減するかを推定することにある。 こ のととは, 海洋牧場における海中緑化システムを運用す るときの基礎データとして重要である. そてで，モデル (10) 式拉よび (11) 式に扔いて, 温度の年変化モデルお よび光強度の年変化モデルのパラメータ中の一つを少し 変化させて, シミュレーションの結果がどのように変わ るかを調べる。

\section{1 温度パラメータに対する感度解析}

まず，温度の年変化モデル (4) 式のパラメータを変化 させるととによるシミュレーションの結果, 次のてとが 分かった。

i ) 年間平均温度 (パラメータ $B_{1}$ ) を上昇することに よって, アカモクの重量は増加し, 重量が最大値 になる日は早くなる. 逆に, 平均温度の低下によっ て，その重量は減少し，最大値になる日も遅くな る. 平均温度が $1{ }^{\circ} \mathrm{C}$ 変化すると, 重量の変化が約 $30 \%$ になる。

ii ) 年間温度変化幅 (パラメータ $B_{2}$ ) を大きくするて とによって, アカモクの成長量が減少する。逆に， その値を小さくするてとよって, その成長量は増 加する. 変化幅が $1{ }^{\circ} \mathrm{C}$ 変化すると, 重量が約 $20 \%$ 変化する. iii) 温度の位相 (パラメータ $t_{\theta}$ ) を早くすると, アカ モクは増産し, 逆に位相を扔くらせると, 減産す る. その位相が十日変動するてとによって，重量 が $5 \%$ ぐらい増減する.

\section{2 光強度のパラメータに対する感度解析}

つぎに，光強度の年変化モデル (2) 式のパラメータを 変化させて, シミュレーションを実行し，その結果を考 察すると, 次のことが分かった。

i ) 年間平均光強度 (パラメータ $A_{1}$ ) $5 \mu \mathrm{E} / \mathrm{m}^{2} \mathrm{~s}$ だ け上昇するてとによって, アカモクの重量は $13 \%$ 増加し，重量が最大になる日は三日早くなる，逆 に, 乙の光強度が同じ程度低下すると, その重量 は $17 \%$ 減少し, 最大になる日も四日遅くなる。

ii ) 年間光強度変化幅 (パラメータ $A_{2}$ )を大きくする ことによって, アカモクの重量は減少する。逆に, その値を小さくするてとによって, その重量は増 加する. その值が $5 \mu \mathrm{E} / \mathrm{m}^{2} \mathrm{~s}$ だけ変化させると， 重量は約 $12 \%$ 変化する.

iii) 光強度の位相 (パラメータ $t_{L}$ )を十日早くすると, アカモクの重量は $1 \%$ 増加する. 逆に, その位相 を十日遅くすることによって, 重量が $2 \%$ 減少す る.

6.1 抢よび 6.2 の感度解析の結果を検証する実デー夕 は，現状では得られていない。しかし，各パラメータを 変化させたときの重量の増減傾向は, 経験的事実に矛盾 するあのではない，また，参考文献 10)では，水温抢よ び照度によって，アラメの配偶体の成長を制御できると いうデータが得られているが, この結果とも矛盾しない ことが分かった。

\section{7. 結 言}

本研究では，のとじま臨海公園水族館におりる測定デ 一タを用いて, 1 年生海藻のアカモクの成長過程を数学 モデルで表現した. アカモクの成長に必要な環境条件の 効果としての光強度効果, 温度効果打よびアカモクに固 有な性質からの季節効果を取り入れて，それぞれの効果 が成長にどのように寄与するかを検討して, 光合成速度 の年変化をモデル化した，その結果，10月から翌年 5 月までの任意の時点に扔けるアカモク単体の重量を推定 する計算式を導出するてとができた。

藻類の動態モデルとして，乙れまで基礎生産に関する モデルには多くの提案がなされているが, 海藻に関して 未だ試みられたことはなかった．したがって，モデルの 妥当性を検証するデー夕あ現状では得られていない.

提案したモデルは, 光合成反応にとって本質的な部分 のみを，現段階で利用可能な実測デー夕を用いて作成し 
たあのである，その意味でモデルはできるだけ単純化さ れており, 得られた結果は, 今後の研究の出発点になる と考えられる. その究極の目的は, 海藻の成長量を予測 するてとができるモデル式を構筑することであるが，そ のために行うべき今後の検討課題を列挙すると次のよう になる。

i ）本研究では，アカモクに関するあらゆるデータを 集めて，それらをつなぎ合わせて利用した．今後 は, 本研究で得られた結果を基にして系統的な実 データの採取法を検討する必要がある. この点に 関して, 我々の研究グループでは測定装置を改善 して，新しいデータの採取を開始したので，その 結果は別の機会に発表したいと考えている.

ii）本モデルの環境パラメー夕に関する感度解析を行っ たが，その妥当性を検証するデータす今後採取す る必要がある.しかし，そのためには多くの年月 を要すると思われる。

iii）モデル (10) 式において, $-\beta N^{2}(t)$ の項の生物学 的な意味づけを検討する必要がある. ての点に関 して実測データでは, 個体の密度が高いほよ゙個体 の成長率が高い場合と逆低低い場合の両方の例が あることが報告されている ${ }^{11)}$. 個体を支える仮根 部が必要とする面積や, 成長に必要な光の量か ら，それ以上は生育できないという飽和密度が存 在すると考えられるが, 水中の場合は陸上植物 ほど密度効果は顕著でないようである。 このよう な問題は今後多くの観察結果を得て議論されるこ とになると思われるが, あしもモデルの信頼性が 高くなれば，シミュレーションによる結果もこの 問題の解決に示唆を与えることができると期待さ れる.

iv）海藻の成長モデルに動物による捕食効果を付加す るととにより, ウニやアワビと海藻の間の捕食者一 被捕食者モデルへ発展させることができる，その 結果から，海洋牧場における最適運用を考える場 合の一つの解答を得ることが期待される.

最後に, 本研究に協力された柴田淳一氏 (現三菱電機) および赤穂貞広氏（現村田製作所）感謝の意を表す。ま た，本研究実施にあたり， CSK 科学技術研究助成より 部分的に援助を受けたてとを付記して謝意を表わす.

\section{参 考 文 献}

1) 黒木 : 海洋牧場におりる計測と魚群の制御 ; 計測と制御, Vol. 24, No. 3, pp. 195〜200 (1985)

2) 三宮: 海洋水産におけるこれからの制御技術; 計測と制御, Vol. 31, No. 1, pp. 166 169 (1992)
3）鈴木 (島津 (編))：内湾におりる低次生産系の数值解析; 資源評価のための数值解析, 恒星社厚生閣, pp 64〜87 (1987)

4) 池田：漁業資源予測と管理のためのモデリング; 計測と制 御, Vol. 24, No. 3, pp. 227 233 (1985)

5）荻野：屋外水槽に自生したアカモクの成長; 動物園水族館 雑誌, Vol. 30, No. 4, pp. 102 106 (1988)

6) 秋山, 有賀, 坂本, 横浜: 藻類の生態, 内田老鶴戋, pp. $1 \sim 51$ (1986)

7) 柴田：光と植物, 培風館 (1982)

8) 高: アカモクの光合成の日変化; 藻類, Vol. 38, pp. 163 165 (1990)

9) K. Gao : Seasonal Variation of Photosynthetic Capacity in Sargassum Horneri ; Jpn. J. Phycol., Vol. 38, pp. 25 33 (1990)

10）谷口, 秋山: アラメ配偶体の成長および成熟に対する水温 と光条件; 東北水研研究報告, Vol. 45, pp. 55 59 (1982)

11) 中原：褐藻類の生活史 XV; 海洋と生物, Vol. 6, No. 3, pp. 216 220 (1984) 
